\title{
Penerapan Intervensi Mendengarkan Murottal Al- Quran Terhadap Penurunan Tekanan Darah Pada Lansia
}

\author{
Via Ifatul Maula ${ }^{1 *}$, Dwi Fijianto ${ }^{2}$ \\ ${ }^{1,2}$ Program Studi Diploma Tiga Keperawatan, Universitas Muhammadiyah Pekajangan \\ Pekalongan, Indonesia \\ *email: viaivatul64@gmail.com
}

\begin{abstract}
Elderly is someone who enters teh age of 60 years or more and experiences physical and physiological changes. Health problems that are commonly experienced by the elderly are hypertension. Hypertension is a health problem characterized by an increase in systolic and diastolic blood pressure of more than $140 / 90 \mathrm{mmHg}$. Non-pharmacological action that is useful in reducing blood pressure is listening to murottal Al-Quran therapy. The purpose of the action is to reduce blood pressure in the elderly with hypertension. This research used the case study method of gerontic nursing care with the therapeutic technique of listening to Al-Quran murottal. The application of Al-Quran murottal listening intervention which was carried our for 7 visits was proven to redue blood pressure in the elderly. The first clien't initial blood pressure was $170 / 100 \mathrm{mmHg}$ to $120 / 90 \mathrm{mmHg}$ (the average drop in systolic pressure is $45-50 \mathrm{mmHg}$ and diastolic is $10 \mathrm{mmHg}$ ), while the second clien't initial blood pressure was $175 / 100 \mathrm{mmHg}$ to $120 / 100 \mathrm{mmHg}$ (the average drop in systolic pressure is $45-$ $50 \mathrm{mmHg}$ and diastolic is $10 \mathrm{mmHg}$ ). this result can be used as a consideration for nurses to provide Al-Quran murottal therapy as an alternative nursing action for the elderly with hypertension.
\end{abstract}

Keywords : Hypertension, Elderly, Al-Quran Murottal listening therapy

\begin{abstract}
Abstrak
Lansia merupakan seseorang yang memasuki usia 60 tahun atau lebih dan mengalami perubahan fisik maupun fisiologis, salah satu masalah kesehatan yang biasa dialami lansia adalah hipertensi. Hipertensi merupakan masalah kesehatan dengan ditandainya kenaikan tekanan darah sistolik dan diastoliknya lebih dari 140/90 mmHg. Tindakan non-farmakologi yang bermafaat dalam penurunan tekanan darah yaitu terapi mendengarkan murottal AlQuran. Tujuan dilakukan tindakan yaitu untuk menurunkan tekanan darah pada lansia hipertensi. Karya Tulis Ilmiah ini disusun dengan menggunakan metode studi kasus asuhan keperawatan gerontik dengan teknik terapi mendengarkan murottal Al-Quran. Penerapan terapi mendengarkan murottal Al-Quran yang dilakukan selama 7 kali kunjungan terbukti dapat menurunkan tekanan darah pada lansia. Lansia klien 1 dengan tekanan darah awal $170 / 100 \mathrm{mmHg}$ menjadi $120 / 90 \mathrm{mmHg}$ (rata-rata penurunan tekanan sistolik $45-50 \mathrm{mmHg}$ dan diastoliknya $10 \mathrm{mmHg}$ ), klien lansia 2 dengan tekanan darah awal 175/100 $\mathrm{mmHg}$ menjadi $120 / 100 \mathrm{mmHg} \mathrm{mmHg}$ (rata-rata penurunan tekanan sistolik $45-50 \mathrm{mmHg}$ dan diastoliknya $10 \mathrm{mmHg}$ ). Perawat diharapkan dapat memberikan terapi Murottal Al-Quran secara maksimal sebagai salah satu alternatif tindakan keperawatan bagi lansia dengan hipertensi.
\end{abstract}

Kata kunci : Hipertensi; Lansia, Terapi Murottal Al-Quran

\section{Pendahuluan}

Word Health Organization (2015) menunjukkan penderita hipertensi sebanyak 1,3 miliar di dunia, dengan kasus hipertensi mengalami peningkatan setiap tahunnya [1]. Tahun 2025 diperkirakan angka hipertensi mencapai 1,5 miliar penderita hipertensi. 


\section{Prosiding Seminar Nasional Kesehatan Lembaga Penelitian dan Pengabdian Masyarakat Universitas Muhammadiyah Pekajangan Pekalongan}

Tahun 2017 prevalensi hipertensi seluruh dunia sekitar 15-20\%. Berdasarkan data Riset Kesehatan Dasar tahun 2016 [2], jumlah penderita hipertensi di Indonesia sebanyak 25,8\% tahun 2013 dan meningkat pada tahun 2018 sebanyak 34,1\% [3].

Hipertensi lebih beresiko dialami oleh lansia. Lansia merupakan seorang laki-laki maupun perempuan yang telah memasuki usia 60 tahun. Lansia merupakan seseorang yang sudah tidak dapat bekerja untuk menuhi kebutuhan sehari-hari karena mengalami perubahan pada fisik. Lansia juga mengalami penurunan pada sistem kekebalan tubuh sehingga rentan mengalami gangguan dari dalam maupun luar [4].

Hipertensi pada lansia memunculkan banyak gejala yang dirasakan, gejala yang biasa muncul seperti sakit kepala, lemas, mual dan muntah dan gejala berlanjut pada peningkatan tekanan darah yaitu stroke, jantung koroner, gagal ginjal, diabetes mellitus, dan penyempitan ventrikel kiri/bilik kiri. Penyakit yang menyerang sistem kardiovaskular pada lansia yang tidak ditangani dengan benar akan menjadi penyebab kematian [5].

Tindakan yang dapat dilakukan untuk meringankan gejala yang dirasakan oleh lansia penderita hipertensi diantaranya ada tindakan farmakologi dan non-farmakologi. Tindakan farmakologi dan non-farmakologi ini penting dilakukan untuk menurunkan tekanan darah pada lansia. Tindakan farmakologi yang berfungsi untuk menurunkan tekanan darah berupa pemberian obat diuretik, beta blocker, vasodilator, alpha blocker, dan inhibator saraf simpatik [6].

Tindakan non-farmakologi yang dapat menurunkan tekanan darah menurut Aspiani (2015) antara lain mempertahankan berat badan ideal artinya berat badan yang sesuai BMI (Body Mass Indeks), mengurangi asupan garam, berhenti merokok, dan manajemen stress. Beberapa tindakan non-farmakologis tersebut dapat berpengaruh untuk menurunan tekanan darah. Terapi non-farmakologi lain untuk menurunkan tekanan darah dapat dilakukan dengan terapi murottal Al-Quran. Terapi murottal menjadi alternatif tindakan non-farmakologi karena memberikan perasaan rileks dan ketenangan sehingga berpengaruh dalam menurunkan tekanan darah [6].

\section{Metode}

Terapi murottal Al-Quran adalah lantunan ayat Al-Quran yang dibacakan oleh qori yang direkam dengan menggunakan media MP3. Terapi murottal Al-Quran diberikan satu hari sekali dalam satu minggu selama 12 menit dengan volume $20 \mathrm{~Hz}$.

Rancangan karya tulis ilmiah yang digunakan penulis adalah metoda studi kasus yaitu rancangan yang mencakup pengkajian secara detail dengan tujuan memberikan gambaran suatu kasus. Penelitian yang dilakukan secara detail pada suatu kasus dengan pengamatan, pengumpulan data, analisa dan pemaparan hasil Nursalam (2017). Rancangan karya tulis ilmiah yang digunakan adalah studi kasus tentang intervensi mendengarkan murottal Al-Quran terhadap penurunan tekanan darah lansia.

Pengumpulan data merupakan teknik pendekatan kepada subyek sebagai proses pengumpulan data yang sesuai dengan karakterikstik suatu penelitian. Prosedur pengumpulan data studi kasus yang digunakan adalah wawancara dan pengamatan. Wawancara dan pengamatan merupakan cara pengumpulan data dimana peneliti mendapatkan data secara lisan yang berasal dari obyek penelitian dan menilai aktivitas yang berhubungan dengan masalah kesehatan Murni (2017). Kriteria instrumen studi kasus meliputi pasien dengan usia 60 tahun atau lebih, mempunyai riwayat hipertensi. Jenis instrumen penelitian yang digunakan dalam penelitian meliputi: Biofisiologis (pengukuran pada fisiologis manusia), observasi untuk pengambilan data yaitu 


\section{Prosiding Seminar Nasional Kesehatan Lembaga Penelitian dan Pengabdian Masyarakat Universitas Muhammadiyah Pekajangan Pekalongan}

dilakukan pengukuran tekanan darah pada dua lansia dengan tensimeter, wawancara yang dilakukan kepada dua lansia dan keluarga tentang bagaimana cara menangani masalah kesehatan, memperoleh fasilitas pelayanan kesehatan dan pemeliharaan kesehatan pada lansia, skala penilaian yang digunakan untuk memperoleh data yaitu dengan penilaian skala nyeri dengan menggunakan numeric rating scale (NRS).

Pengolahan data yang disajikan karya tulis ilmiah adalah data yang diperoleh melalui wawancara dan observasi pada klien kemudian dilakukan analisa dengan tujuan untuk menentukan masalah keperawatan yang muncul. Setelah diagnosa keperawatan muncul kemudian menyusun intervensi keperawatan dengan tujuan untuk mengatasi masalah keperawatan dan menentukan kriteria hasil serta evaluasi. Tersusunnya intervensi kemudian diimplementasikan dan dilakukan evaluasi untuk mengetahui keberhasilan tindakan keperawatan. Data yang sudah terkumpul kemudian ditulis dan dibahas dalam bentuk narasi mulai dari pengkajian sampai evaluasi.

\section{Hasil dan Pembahasan Hasil}

Hasil studi kasus yang didapatkan pada dua subyek studi kasus yang menderita hipertensi mengalami penurunan tekanan darah dan penurunan nyeri setelah dilakukan terapi mendengarkan murottal Al-Quran. Pada subyek 1 tekanan darah sebelum dilakukan terapi $170 / 100 \mathrm{mmHg}$ (rata-rata penurunan tekanan sistolik $45-50 \mathrm{mmHg}$ dan diastolik $10 \mathrm{mmHg}$ ) dengan skala nyeri 4 (nyeri terasa cekot-cekot), setelah dilakukan terapi tekanan darah mengalami penurunan menjadi $120 / 90 \mathrm{mmHg}$ dengan skala nyeri 1 (nyeri tidak dirasakan). Pada subyek 2 tekanan darah sebelum dilakukan terapi $175 / 100 \mathrm{mmHg}$ dengan skala nyeri 5 (nyeri terasa cekot-cekot), setelah dilakukan terapi tekanan darah mengalami penurunan menjadi $120 / 100 \mathrm{mmHg}$ dengan skala nyeri 1.

Evaluasi hasil yang didapatkan selama 7 kali kunjungan klien 1 dengan tekanan darah $170 / 100 \mathrm{mmHg}$ menjadi $120 / 90 \mathrm{mmHg}$ dengan skala nyeri awal 4 (nyeri terasa cekot-cekot) turun menjadi 1 (nyeri tidak dirasakan), klien 2 tekanan darah awal $175 / 100 \mathrm{mmHg}$ menjadi 120/100 mmHg dengan skala nyeri awal 5 (nyeri terasa cekotcekot) turun menjadi 1 (nyeri tidak dirasakan), nyeri berkurang, dan keluarga dapat memberikan terapi murottal secara mandiri dengan rata-rata penurunan tekanan sistolik $45-50 \mathrm{mmHg}$ dan diastolik $10 \mathrm{mmHg}$, dengan kriteria skala nyeri 2-1 yaitu nyeri ringan atau tidak dirasakan.

\section{Pembahasan}

\section{Intervensi Keperawatan}

Hasil studi kasus didapatkan bahwa dari dua subyek studi kasus yang menderita hipertensi mengalami penurunan tekanan darah setelah dilakukan tindakan terapi mendengarkan murottal Al-Quran. Hasil studi kasus sesuai dengan penelitian Despitasari et al., (2018), yang menjelaskan bahwa terapi mendengarkan murottal AlQuran yang dilakukan selama tujuh hari berturut-turut yang bertujuan untuk menurunkan tekanan darah pada lansia hipertensi. Rencana tindakan keperawatan yang disusun sesuai dengan Majid (2017), yang meliputi monitor TTV, kaji nyeri, berikan posisi nyaman, ajarkan teknik relaksasi (mendengarkan murottal Al-Quran), 


\section{Prosiding Seminar Nasional Kesehatan Lembaga Penelitian dan Pengabdian Masyarakat Universitas Muhammadiyah Pekajangan Pekalongan}

dan anjurkan istirahat cukup. Rasional tindakan keperawatan pada dua subyek studi kasus yaitu mengetahui kualitas nyeri, memberikan rasa nyaman, menurunkan tekanan darah dan untuk mengurangi nyeri pada subyek studi kasus.

Tindakan non-farmakologi terapi mendengarkan murottal Al-Quran, sesuai dengan Solehati \& Kokasih (2015), dengan menggunakan terapi murottal Al-Quran (surah ArRahman) yang diperdengarkan pada telinga klien selama 12 menit, yang dilakukan sehari sekali.

\section{Implementasi Keperawatan}

Hasil studi kasus yang penulis lakukan menunjukkan pada dua subyek studi kasus lansia hipertensi dengan melakukan penatalaksanaan nyeri akut dengan tindakan nonfarmakologi (terapi mendengarkan murottal Al-Quran), kasus 1 tekanan darah sebelum dilakukan tindakan terapi $170 / 90 \mathrm{mmHg}$ dengan skala nyeri 4, setelah dilakukan terapi tekanan darah menurun menjadi $120 / 90 \mathrm{mmHg}$ dengan skala nyeri 1 dan kasus 2 tekanan darah sebelum dilakukan tindakan terapi $175 / 100 \mathrm{mmHg}$ dengan skala nyeri 5, setelah dilakukan terapi tekanan darah menurun menjadi $120 / 100 \mathrm{mmHg}$ dengan skala nyeri 1. Menurut Solehati \& Kokasih (2015), implementasi menggunakan murottal Al-Quran ini dilakukan untuk menurunkan nyeri akut yang disebabkan oleh peningkatan tekanan darah. Hal tersebut juga sesuai dengan penjelasan dari Despitasari et al., (2018), yang menjelaskan bahwa terapi murottal dapat menurunkan nyeri akut pada klien hipertensi. Terapi ini diharapkan dapat menurunkan tekanan darah dalam batas normal maupun mengontrol nyeri dan dapat menunjukan bahwa terapi mendengarkan murottal Al-Quran efektif digunakan untuk klien hipertensi. Implementasi yang telah dilakukan penulis yaitu memonitor TTV, mengkaji nyeri, mengajarkan teknik relaksasi, dan menganjurkan klien untuk istirahat cukup sesuai teori dari Majid (2017) dan didukung oleh teori Despitasari et al., (2018) dan Erlina (2015), yang menjelaskan bahwa implementasi yang dilakukan pada penderita hipertensi diantaranya monitor TTV, ajarkan teknik relaksasi, dan istirahat cukup.

\section{Kesimpulan}

Penerapan mendengarkan murottal Al-Quran terbukti dapat menurunkan tekanan darah pada lansia hipertensi.Data yang didapatkan dari hasil pengkajian yang penulis lakukan pada kasus 1 data pasien mengeluh sakit kepala dengan skala 4, hasil pemeriksaan TD 170/100 $\mathrm{mmHg}$. Data pada kasus 2 pasien mengeluh sakit kepala dengan skala 5, hasil pemeriksaan TD 175/100 mmHg. Diagnosa keperawatan yang muncul dari data hasil pengkajian tersebut yaitu pada kasus 1 dan 2 sama yaitu nyeri (sakit kepala). Rencana tindakan keperawatan yang bertujuan untuk mengatasi masalah keperawatan lansia dengan hipertensi yaitu monitor TTV, kaji nyeri, ajarkan teknik relaksasi (mendengarkan murottal Al-Quran), anjurkan istirahat cukup, dengan kriteria hasil klien mengatakan nyeri berkurang, tekanan darah dalam batas normal (tekanan sistolik $140 \mathrm{mmHg}$ dan tekanan diastolik $90 \mathrm{mmHg}$ ) dan klien nampak rileks. Tindakan keperawatan yang sudah dilakukan penulis sesuai dengan yang rencana tindakan keperawatan yang sudah tersusun dalam waktu 7 kali kunjungan dengan memberikan tindakan mendengarkan murottal Al-Quran. Evaluasi tindakan keperawatan setelah 7 kali kunjungan yaitu nyeri teratasi ditandai dengan tekanan 


\section{Prosiding Seminar Nasional Kesehatan Lembaga Penelitian dan Pengabdian Masyarakat Universitas Muhammadiyah Pekajangan Pekalongan}

darah normal pada kasus 1 yaitu 120/90 mmHg (rata-rata penurunan tekanan darah sistolik $45-50 \mathrm{mmHg}$ dan diastolik $10 \mathrm{mmHg}$ ), dengan skala nyeri 5 menjadi 1 sedangan pada kasus 2 yaitu 120/100 $\mathrm{mmHg}$ (rata-rata penurunan tekanan darah sistolik 45-50 mmHg dan diastolik $10 \mathrm{mmHg}$ ), dengan skala nyeri 5 menjadi 1.

\section{Saran}

Bagi pasien yaitu klien mampu mengontrol tekanan darah agar tidak terjadi komplikasi dengan menerapkan terapi murottal Al-Quran sebagai terapi nonfarmakologi yang dapat menurunkan tekanan darah. Perkembangan ilmu pengetahuan dan teknologi keperawatan diharapkan Karya Tulis Ilmiah ini dapat menjadi referensi tindakan non-farmakologi untuk menurunkan tekanan darah pada lansia hipertensi. Untuk penulis selanjutnya untuk lebih meningkatkan untuk mengelola asuhan keperawatan lansia dengan hipertensi dengan tindakan non-farmakologi untuk menurunkan tekanan darah. Dan untuk tenaga keperawatan khususnya perawat setelah membaca Karya Tulis Ilmiah ini, diharapkan memiliki ketrampilan dalam memberikan asuhan keperawatan khususnya bagi lansia dengan hipertensi dapat menggunakan terapi non-farmakologi yaitu terapi mendengarkan murottal Al-Quran untuk menurunkan tekanan darah.

\section{Referensi}

[1] Organization, W. H._Hasil Utama Riskesdas 2018. Diambil dari https://ww.kemenkes.go.id/article/view/1905170000/hipertensi-penyakit-palingbanyak-diidap-masyarakat.html. 2015

[2] Kementrian Kesehatan RI. Infondation Hipertensi. Jakarta : Kementrian Kesehatan RI. 2016

[3] $\mathrm{Ri}$, K. K. Hasil Utama Riskesdas 2018. Diambil dari https://ww.kemenkes.go.id/article/view/1905170000/hipertensi-penyakit-palingbanyak-diidap-masyarakat.html. 2018

[4] Ratnawati, E. Asuhan Keperawatan Gerontik. Yogyakarta : PUSTAKA BARU PRESS, 2017.

[5] Amalis. Efektifitas Intervensi Musik Klasik Terhadap Stress Dalam

Menyusun Skripsi Pada Mahasiswa. Semarang : PSIK UNDIP Semarang, 2015.

[6] Aspiani, Y.R. Buku Ajar Asuhan Keperawatan Klien Gangguan Kardiovaskular Aplikasi NIC \& NOC. Jakarta : EGC, 2015.

[7] Nursalam. Metodologi Penelitian Ilmu Keperawatan Pendekatan Praktis Edisi 4. Jakarta : Salemba Medika, 2017.

[8] Murni. Instrumen Pengumpulan Data. Diambil dari https://osf.io/preprints/inarxiv/s3kr6/download. 2017

[9] Despitasari, L., Afrizal., \& Umar, M. Pengaruh mendengarkan Al-Quran terhadap perubahan tekanan darah pada lansia penderita hipertensi diwilayah Puskesmas Andalas Padang tahun 2018". Jurnal Kesehatan Mercusuar. 2 (1), 8-8, 2019. Diambil http://jurnal.mercubaktijaya.ac.id/index.php/mercusuar/article/view/26

dari 


\section{Prosiding Seminar Nasional Kesehatan Lembaga Penelitian dan Pengabdian Masyarakat

[10] Majid, A. Asuhan Keperawatan pada Pasien Dengan Gangguan Sistem Kardiovaskular. Yogyakarta : PUSTAKA BARU PRESS, 2017.

[11] Solehati, T., \& Kokesih, CE. Konsep dan Aplikasi Relaksasi Dalam Keperawatan Maternitas. 2015.

Diambil

dari https://scholar.google.com/scholar?cluster $=6841210887519349135 \&$ hl=en\&oi=s cholar\#d=gs qabs\&u=\%23p\%3DjykgUA8F4J 